\title{
The Impact of Marketing Strategy on Profitability in Medical Jordanian Corporations
}

\author{
Munther Al-Nimer ${ }^{1}$, Moh'd Fayez Qasem ${ }^{2}$, Mohammad “Abd Alaffo" AlAdham ${ }^{3} \&$ Ammar Ali Yousef $^{4}$ \\ ${ }^{1}$ Faculty of Business, Effat University, Saudi Arabia \\ ${ }^{2}$ Sales \& Marketing Director, Masader For Student Services, Amman, Jordan \\ ${ }^{3}$ Operations Director, Masader For Student Services, Amman, Jordan \\ ${ }^{4}$ Financial Manager, Saba Marine Services Co Ltd, Jordan \\ Correspondence: Munther Al-Nimer, School of Business, Effat University University, PO Box 34689, Jeddah \\ 21478, Saudi Arabia. E-mail: mualnimer@effatuniversity.edu.sa
}

Received: July 23, 2015

Accepted: August 21, 2015

Online Published: October 26, 2015

doi:10.5539/ibr.v8n11p61

URL: http://dx.doi.org/10.5539/ibr.v8n11p61

\begin{abstract}
Marketing and advertising is a fundamental factor in the deployment of companies' name and increase their profits, Therefore, this study aimed to identify whether there is an impact between Marketing and advertising expenses and profitability in industrial medicines public shareholding companies listed in the Amman Stock Exchange.

The sample of the study included the industrial pharmaceutical companies listed in the Amman Stock Exchange, during the period between 2009-2013. To achieve the purposes of the study, and to analyze the data extracted from the annual statements, the researcher used simple linear regression method.

The results of the study showed an impact of marketing and advertising expenses on the profitability of the pharmaceutical companies.

The paper provides a useful guide for the users of financial statements of Marketing and Advertising, since it provides information on possible effect on the company's performance. In addition, the paper fills an information gap by addressing a range of valuation issues on Marketing and Advertising and offers relevant information guidance to the users of financial statements.
\end{abstract}

Keywords: marketing, advertising, profitability, net profit

\section{Introduction to the Research}

Marketing Management aims for the creation of long-term links with customers in order to obtain their fidelity, loyalty, and profitability (Anderson et al., 2004). This objective has led companies to direct more resources towards their marketing activities (Kumar \& Basu, 2008), but it also requires them to justify these investments (Ambler et al., 2004).

Managers and academics are tasked with demonstrating how marketing increases the financial capital of firms (McDonald, 2006). In this context, Return on Marketing Investment (ROMI) has been proposed as a management philosophy to transform companies' commercial actions into financial results (Cook \& Talluri, 2004).

In this context this study examined the period (2009-2013) to explore and analyze the Impact of Marketing Expenses on Companies Profitability measured by net profit, by using content analyses method, to have the ability to evaluate the effect of the expenses of marketing and to recommend how to come over its benefits.

In the light of this, the problem of this study comes from the lack of interest in advertising expenses, such expenses should not be viewed as an expense must be reduced, but attention must be paid to these expenses as it relates to a close relationship with companies' profits, especially when talking that all commercial companies aim to have the continuity of their business and maximize their profits.

In addition, several studies have been conducted in order to measure the effect of different variables upon the financial performance, for instance; Sleihat et al. (2012), Al-Nimer et al. (2012), Warrad et al. (2013), Al-Nimer 
et al. (2013), Al-Nimer (2015), and Al-Nimer and Sleihat (2015) in the Jordanian context. Therefore the problem of the study can be summarized by answering the following question:

Is there a statistically significant Impact of advertising and marketing expenses on companies Net Profits?

\section{Literature Review}

There were many previous studies related to this study, where every study took deferent variables.

Whereas Oneill et al. (2008) endeavors to fill the void in the lack of investigating the relative benefits of the different areas where those funds can be invested. This study examines marketing expenditures for various hotel tiers, using the Smith Travel Research chain scale categorizations. the researcher found that marketing expenditures have differential effects according to the particular type of marketing expenditure.

On the other hand Hardesty and Leff (2010) conducted detailed case studies of three organic farming operations of different sizes and compared their marketing costs and profitability in alternative marketing channels. The researchers classified marketing-related activities into three categories: packing and storage, transportation, and selling and administration. The researchers determined that there are significant variations in marketing costs across marketing channels. For each of three case study farms, marketing costs per dollar of revenue were lowest in the wholesale channel and highest in the farmers' market channel. Significant labor costs for the selling activity and transportation expenses offset the higher prices and minimal packaging costs associated with farmers' markets. Profitability can also be significantly affected by marketing factors such as packing and grading standards and product that is used for sampling and consumer premiums.

While Morgan et al. (2009) investigated how market sensing, brand management, and customer relationship management (CRM) capabilities determine firms' revenue growth and margin growth (the two components of profit growth). The study reveals that marketing capabilities have direct and complementary effects on both revenue and margin growth rates, and also found that brand management and CRM capabilities have opposing effects on revenue and margin growth rates, such that a failure to examine these two underlying components would mask the relationships between these marketing capabilities and ultimate profit growth rates.

On the other hand Morgan et al. (2009) examine both the possession of a market orientation and the marketing capabilities through which resources are deployed into the marketplace as drivers of firm performance. The researcher's findings indicate that market orientation and marketing capabilities are complementary assets that contribute to superior firm performance. They also find that market orientation has a direct effect on firms' return on assets (ROA), and that marketing capabilities directly impact both ROA and perceived firm performance.

As to Krasnikov and Jayachandran (2008), they examined the effect of marketing capability on firm performance on other capabilities, such as research and development and operations. The researchers found that marketing capability in general, has a stronger impact on firm performance than research-and-development and operations capabilities.

Where Rodriguez and Berrio (2011) studied the relationship between Market Orientation (MO) concept and Financial Performance (FP) in Bogota-based MSMEs. They found that there is no statistically significant impact between Market Orientation construct (intelligence generation; intelligence dissemination; response planning; and response implementation) and Financial Performance (Net Sales, Operating Profit, and their ratio to assets).

And about Bharadwaj et al. (2005) using new developments in endogenous growth theory, this article explores the link between marketing actions and market growth. In particular, the authors develop a conceptual model arguing that the effect of endogenous actions on market growth is mediated by knowledge creation, matching, and diffusion. Propositions are proposed to guide future research. The authors discuss the implications for marketing strategy at both business discipline and public policy levels.

Ambler et al. (2004) asks what is the difference between brand equity and customer equity. Does the distinction matter? Is there a difference between the firm's brand asset and customer asset? What are the implications of taking a brand perspective versus a customer perspective when designing and implementing marketing programs? The objective of this article is to examine these two perspectives in depth so that researchers and managers can improve their understanding and use of customer and brand perspectives on marketing. The authors seek to determine the relationship between the two assets and perspectives in terms of similarities and differences. They examine the development of customer and brand perspectives and describe how each adds value to the firm and to the customer. Subsequently, they delineate possible approaches for measuring marketing assets. They discuss key issues researchers and practitioners should consider in managing marketing assets, particularly for multiband companies. They conclude by suggesting future research directions. 
As for Capron and Hulland (1999) they examined the effects of redeployment on subsequent product costs, product quality, product line breadth, geographic market coverage, market share, and profitability. They result that Cost-based synergies were minimally affected, but revenue-based synergies and overall firm performance were significantly influenced.

\section{Research Methodology}

The study will rely on the analysis of data on the descriptive analytical method, so as to appropriateness of the nature of the study, which will be the theoretical framework for the study to determine based on references and periodicals on the subject, and to collect financial data researcher relied on annual financial reports of Medical Jordanian corporations between the years 2009-2013.

\subsection{Purpose of This Research}

Objectives of the study are summarized in the presentation of advertising and marketing expenses impact on companies' profitability, and determine how the use of the advertising and marketing expenses, in order to increase company's profitability.

\subsection{Research Importance}

The study importance arises from the importance of paying for marketing and advertising expenses, and its effect on increasing companies' profitability (in short and long run). where it's believed that the company's reputation is affected by the size of marketing and advertising, which in turn affect profitability. Furthermore, there is a lack of studies which examine the effect of marketing specially in the Jordanian context as most of the studies examined other variables such as market capitalization, earnings per Share, dividends per Share, ownership concentration, liquidity, and capital structure for instance (Al-Nimer et al., 2013; Al-Nimer, 2015; Warrad et al., 2013).

\subsection{Hypothesis}

Ho1: There is no impact between advertising and marketing expenses and net profits in medical industrial companies listed in Amman stock exchange.

\subsection{Research Population}

This study represents a population of industrial companies listed on Amman Stock Exchange, where the study population consisted of 68 Jordanian industrial companies.

\subsection{Research Sample}

The study sample consisted of (6) Medical Industrial companies, equivalent to (9\%) of the study population, where the researcher used purposive sample method, during the period 2009-2013.

\subsection{Research Model}

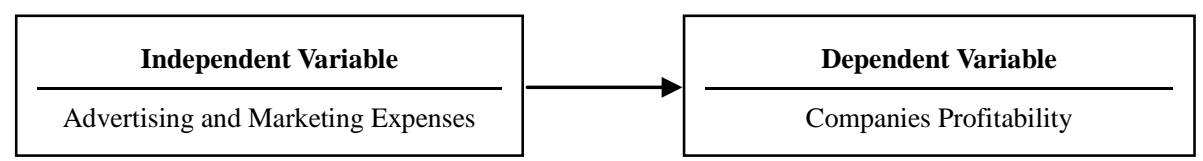

\section{Data analysis methods}

For the purposes of achieving the objectives of the study, the researcher used the following statistical methods:

1) Descriptive statistical methods: Where the researcher will analyze the study data descriptive analysis. In order to extract several measures of statistical and descriptive, such as mean, standard deviation, and others.

2) Test the hypotheses of the study by using the model of simple regression, in order to test the impact of the independent variable on the dependent variable in this study, in addition to the use of any other methods suitable deems necessary researcher, will researcher using statistical analysis (SPSS) program for this purpose.

\subsection{Sources of Information Gathering}

For the purposes of achieving the objectives of the study and testing of Hypothesis, it has been collecting evidence of the following ways:

1. Primary sources: the financial statements for public shareholding Medical Jordanian corporations during the 
period 2009-2013.

2. Secondary sources: Include periodicals, articles, books in addition to previous studies close to this research, in order to The theoretical aspect of the study cover.

\section{Results and Discussion}

After gathering the data of the research, and based on the statically methods used in the previous chapter. The data that was gathered was analyzed to extract the results of the working companies in the insurance sector listed in Amman stock market.

This chapter includes three main aspects; the first one is concerned with the descriptive tests of the study variables. The second aspect is the further assurance that there is no problems in the correlation between variables, as for the third aspect it represents testing the study thesis by calculating the factors of the regression and discussing the results, and then the test of simple linear regression, after that setting equations to predict the following study variable based on the variable of the independent study, using the results of the study as follows:

$Y 1$ indicates: Companies Profitability (Net Income).

$$
Y 1=\beta 0+(\beta 1 X 1)+e
$$

$X 1$ indicates: Advertising and Marketing Expenses.

$B 0-\beta 1$ : indicates the regression factor.

$e$ : error.

\subsection{Descriptive Tests}

Table 1. Descriptive statistics

\begin{tabular}{lllll}
\hline & Minimum & Maximum & Mean & Std. Deviation \\
\hline Companies Profitability (Net Income) & 20903 & 9111137 & 1600580.06 & 2376165.7 \\
Selling and Distribution Expenses & 104063 & 20093922 & 5021125.6 & 5493278.9 \\
\hline
\end{tabular}

The following table shows the descriptive analysis of the variables of the study, noted that the arithmetic average of the independent variable (Advertising and Marketing Expenses) has reached (5021125.6), and the arithmetic average has reached the dependent variable (Companies Profitability (Net Income) (1600580.06).

\subsection{Test the Validity of the Data for Statistical Analysis}

Must be at the beginning and before the beginning of the process of analysis and hypothesis testing to know the data characteristics in terms of verification of the suitability of the study sample to conduct the normal distribution of variables were tested, where the simple linear regression assumptions stipulates the need for the distribution of views of independent variables and the dependent variable normal distribution, and in the case of failure to follow any of the study variables normal distribution, should be used for data analysis tests with normal distribution is as follows shapes (Histograms) show that the natural distribution of the variables of the study.

Companies Profitability (Net Income).

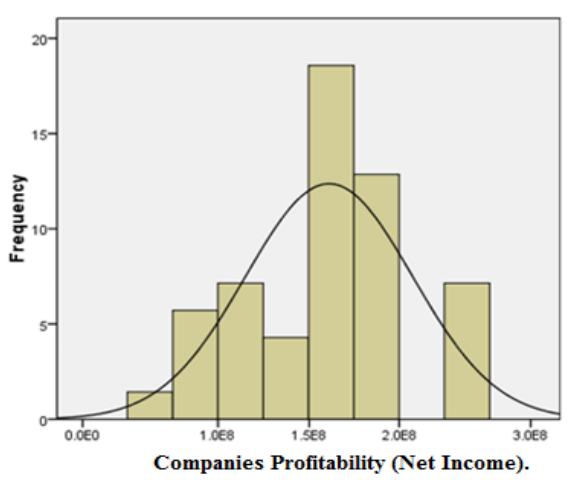

Advertising and Marketing Expenses

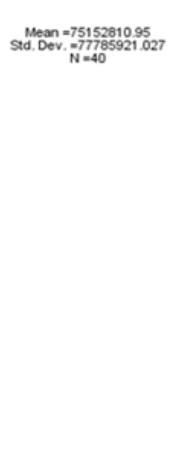

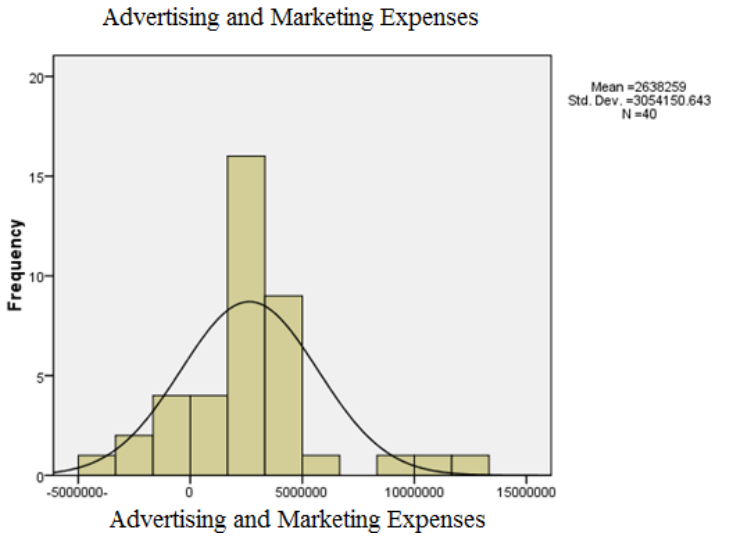

Figure 1. The normal distribution of the variable independent study and the dependent variable 
Figure shows the normal distribution of the variable independent study and the dependent variable, respectively (Companies Profitability (Net Income)) \& (Advertising and Marketing Expenses), when working Profitability in Medical Jordanian Corporations, according to this figure, it is clear that the variables distributor distributed naturally, and thus will be used for parametric tests of the data on this variable.

\subsection{Testing the Study Thesis}

H1: There is No impact between Advertising and Marketing Expenses and Net Profits in Medical Industrial Companies Listed in Amman Stock Exchange.

To prove or deny this thesis, the other thesis branched from this one were tested, and as you continue reading you will find the results of those tests, and then the discussion and the comparison of those results with previous studies results. The value of the (sig) was used to determine whether to accept or deny the thesis. If (sig $<=5 \%$ ), then the thesis reject, if anything else it will be to accept the alterative hypothesis. It also displays then percentage in which every independent variable is explained in the process of changing depending on the variable that is followed; this result is based on the (R square).

H2: There is No impact between Advertising and Marketing Expenses and Net Profits in Medical Industrial Companies Listed in Amman Stock Exchange.

\begin{tabular}{lllll}
\hline Sig & t- statistics & Coefficients & Constant B & Advertising and Marketing Expenses B \\
\hline 0.009 & 2.817 & 0.470 & 580056.457 & 0.203 \\
& \multicolumn{4}{c}{ R Square } \\
$0.221 ;$ Model F test 7.933 \\
\hline
\end{tabular}

The previous schedule shows the results of the simple linear regression analysis for the independent variable (Advertising and Marketing Expenses) and its effect on Net Profits, it shows that the R Square is (0.221), which simply indicates that the net profits the percentage in the change in advertising and marketing expenses, As shown that the relationship between variables is a positive relationship by the value of the type (Coefficients) the amount $(0.470)$, the results indicated that the value of ( $\operatorname{sig} 0.009 \%<5 \%)$ which in means the reject sub hypothesis and be to accept the alterative hypothesis " There is impact between Advertising and Marketing Expenses and Net Profits in Medical Industrial Companies Listed in Amman Stock Exchange”.

Based on the results of the single regression analysis of the thesis, we can form the following equation, for all the study variables:

$$
Y 1=580056.457+(0.203 \times X 1)+e
$$

Where:

$Y 1$ indicates: Companies Profitability (Net Income).

$X 1$ indicates: Advertising and Marketing Expenses.

$e$ : error.

\section{Concluding Remarks}

Marketing has been, and continues to be, a combination of art and science. With the increasing availability of data and sophistication in methods, it is now possible to study the effect of marketing on many important and crucial factors. In this research the researcher discussed the marketing and advertising expenses and its effect on companies' profitability measured by net profit.

The study found that there is impact between Advertising and Marketing Expenses and Net Profits in Medical Industrial Companies Listed in Amman Stock Exchange. The study believes that the reason for this is due to the nature of the advertising expenses have a direct impact in improving the company's reputation, and raise the market value and competitiveness. Thereby increase their profits and improve their place among the competitors.

\section{Limitations and Directions for Further Research}

The study results a statistical impact between advertising and Marketing Expenses and Net Profits in Medical Industrial Companies Listed in Amman Stock Exchange, Therefore, the study recommends managements in Jordanian pharmaceutical companies to use all the means that will enhance marketing and advertising have, in all of its forms, where it is the main source to increase the company's reputation and improve its reputation and expand its work scope. The study recommends re-conduct research on other samples such as banks; beside to re-conduct research on other period of time includes the global crisis. Finally, the study suggested examining the 
impact of Advertising and Marketing Expenses on other dependent factors using questionnaire tool.

\section{References}

Al-Nimer, M. (2013). The Effect of Market Capitalization on Stock Price: A case study from Jordanian Banks. International Journal of Marketing, Financial Services, and Management Research, 2(3).

Al-Nimer, M. (2015). Factors Affecting Mandatory Audit Rotation Evidence from Jordan. International Journal of Economics and Finance, 7(6).

Al-Nimer, M. (2015). Perceptions of Environmental Accounting in the Jordanian Pharmaceutical Industries (Applications and Disclosure). International Journal of Business and Management, 10(2).

Al-Nimer, M., \& Sleihat, N. (2015). The Effect of Profitability Ratios on Market Capitalization in Jordanian Insurance Companies Listed in Amman Stock Exchange. Journal of Economics and Sustainable Development, 6(6).

Al-Nimer, M., Sleihat, N., Al-Abbadi, H., \& Almahamid, S. (2012). The Diffusion of Performance Evaluation Measures: An Empirical Study in Jordanian Banks. International Journal of Business and Management, Canadian Center of Science and Education, 7(14), 76-87.

Al-Nimer, M., Warrad, L., \& Alomri, R. (2013). The Effect of Return on Assets and Earnings per Share and Dividends per Share on Stock Price of Publicly Listed Banks in Jordan. International Journal of Marketing, Financial Services, and Management Research, 2(3).

Al-Nimer, M., Warrad, L., \& Alomri, R. (2013). The Impact of Liquidity on Jordanian Banks Profitability through Return on Assets. Interdisciplinary Journal of Contemporary Research in Business, 5(7), 70-76.

Ambler, T., Kokkinaki, F., \& Puntoni, S. (2004). Assessing marketing performance: Reasons for metrics selection. Journal of Marketing Management, (20), 475-498.

Anderson, E., Fornell, C., \& Mazvancheryl, S. (2004). Customer satisfaction and shareholder value. Journal of Marketing, (68), 172-185.

Bharadwaj, S., Clark, T., \& Kulviwat, S. (2005). Marketing, market growth, and endogenous growth theory: An Inquiry into the causes of market growth. Journal of the Academy of Marketing Science, 33(3), 347-359.

Capron, L., \& Hulland, J. (1999). Redeployment of brands, sales forces, and general marketing management expertise following horizontal acquisition: A resource based view. Journal of Marketing, 63(2), 41-54.

Cook, W., \& Talluri, V. (2004). How the Pursuit of ROMI is changing marketing management. Journal of Advertising Research, 44(3), 244-254.

Hardesty, S. D., \& Leff, P. (2010). Determining marketing costs and returns in alternative marketing channels. Renewable Agriculture and Food Systems, 25(1).

Krasnikov, A., \& Jayachandran, S. (2008). The relative impact of marketing, research and development, and operations capabilities on firm performance. Journal of Marketing, 72(4), 1-11.

Kumar, M., \& Basu, P. (2008). Effectiveness of marketing expenditures: A brand level case study. Journal of Targeting. Measurement and Analysis for Marketing, 16(3), 181-188.

McDonald, M. (2006). Do your marketing strategies create or destroy shareholder value? Database Marketing and Customer Strategy Management, 13(2), 102-107.

Morgan, N. A., Slotegraaf, R. J., \& Vorhies, D. W. (2009), Linking marketing capabilities with profit growth. International Journal of Research in Marketing, 26, 284-293.

Morgan, N. A., Vorhies, D. W., \& Mason, C. (2009). Market orientation, marketing capabilities, and firm performance. Strategic Management Journal, 30(8), 909-920.

Oneill, J. W., Hanson, B., \& Mattila, A. S. (2008). The relationship of sales and marketing expenses to hotel performance in the united states. Cornell Hospitality Quarterly, 49(4), 355-363.

Rodriguez, R. A., \& Berrio, S. P. (2011). The impact of market orientation on the financial performance of MSMES (micro, small and medium enterprises) in Bogota. Papers Administration Valley University, 27(6), 131-140.

Sleihat, N., Al-Nimer, M., \& Alabbadi, S. (2012). The Effect of Advanced Technology on the Implementation of Costing System Practices: Case of Jordan. Administrative Sciences Journal (Dirasat), 39(1), 107-118.

Warrad, L., Almahamid, S., Slihat, N., \& Al-Nimer, M. (2013). The Relationship between Ownership Concentration and Company Performance, A Case of Jordanian Non-Financial Listed Companies. Interdisciplinary Journal of Contemporary Research in Business, United Kingdom, 4(9), 17-38. 
Warrad, L., Sleihat, N., Alomari, R., Al-Nimer, M. (2013). The Impact of Profitability on Obtaining Debt through the Financial Leverage: Comparative Study among Industrial Sectors in Jordan. Interdisciplinary Journal of Contemporary Research in Business, 5(3), 25-34.

\section{Copyrights}

Copyright for this article is retained by the author(s), with first publication rights granted to the journal.

This is an open-access article distributed under the terms and conditions of the Creative Commons Attribution license (http://creativecommons.org/licenses/by/3.0/). 